\title{
Mutation analysis of glycine decarboxylase, aminomethyltransferase and glycine cleavage system protein-H genes in 13 unrelated families with glycine encephalopathy
}

\author{
Nor Azimah Abdul Azize ${ }^{1}$, Wan Zurinah Wan Ngah ${ }^{2}$, Zulhabri Othman ${ }^{2}$, Norsiah Md Desa ${ }^{1}$, Chen Bee Chin ${ }^{3}$, \\ Zabedah Md Yunus ${ }^{4}$, Anand Mohan ${ }^{5}$, Teh Siao Hean ${ }^{6}$, Syed Zulkifli Syed Zakaria ${ }^{2}$ and Ngu Lock-Hock ${ }^{3}$
}

Glycine encephalopathy (GCE) or nonketotic hyperglycinemia is an inborn error of glycine metabolism, inherited in an autosomal recessive manner due to a defect in any one of the four enzymes aminomethyltransferase (AMT), glycine decarboxylase (GLDC), glycine cleavage system protein-H (GCSH) and dehydrolipoamide dehydrogenase in the glycine cleavage system. This defect leads to glycine accumulation in body tissues, including the brain, and causes various neurological symptoms such as encephalopathy, hypotonia, apnea, intractable seizures and possible death. We screened 14 patients from 13 families with clinical and biochemical features suggestive of GCE for mutation in AMT, GLDC and GCSH genes by direct sequencing and genomic rearrangement of GLDC gene using a multiplex ligation-dependant probe amplification. We identified mutations in all 14 patients. Seven patients (50\%) have biallelic mutations in GLDC gene, six patients (43\%) have biallelic mutations in $A M T$ gene and one patient (7\%) has mutation identified in only one allele in GLDC gene. Majority of the mutations in GLDC and $A M T$ were missense mutations and family specific. Interestingly, two mutations p.Arg265His in $A M T$ gene and p.His651Arg in GLDC gene occurred in the Penan sub-population. No mutation was found in GCSH gene. We concluded that mutations in both GLDC and $A M T$ genes are the main cause of GCE in Malaysian population.

Journal of Human Genetics (2014) 59, 593-597; doi:10.1038/jhg.2014.69; published online 18 September 2014

\section{INTRODUCTION}

Glycine encephalopathy (GCE, MIM \#605899, also known as nonketotic hyperglycinemia) is an autosomal recessive disorder of glycine metabolism due to a defect in the glycine cleavage system (EC 2.1.2.10). ${ }^{1}$ The glycine cleavage system is a mitochondrial multienzyme system consisting of four protein components: three specific components (P-, T- and H-protein) and one housekeeping enzyme (L-protein). ${ }^{2}$ P-protein is encoded by glycine decarboxylase gene $(G L D C)$, aminomethyltransferase gene (AMT) encodes T-protein, glycine cleavage system protein-H gene $(G C S H)$ encodes H-protein and dehydrolipoamide dehydrogenase gene encodes L-protein. Defect in any one of the four enzymes in the glycine cleavage system may lead to glycine accumulation in body tissues, including the brain. Glycine which functions as a neurotransmitter, if present at high levels, in the brain could induce severe neuronal dysfunction. ${ }^{3}$

GCE is a rare disorder in most populations except in Northern Finland (1:12000 newborns) and British Columbia (1:63000 newborns). ${ }^{4}$ Most commonly GCE presents as the neonatal form of disease, manifests within a few days of birth with progressive lethargy, hypotonia and myoclonic seizures leading to apnea and possible death if not supported by mechanical ventilation. The majority of the surviving infants have profound psychomotor retardation and treatment-resistant epilepsy; although a small number of them may make developmental progress to a variable degree. ${ }^{5-7}$ The infantile form of the disease is less common, characterized by early-onset hypotonia, developmental delay, seizures and the outcome may be mild or severe. Atypical form of GCE has been reported, with onset from childhood to adulthood, ranging from milder disease (mild learning difficulties, behavioral problems and choreoiform movement disorders) to severe disease (spastic paraparesis, optic atrophy, pulmonary hypertension and vacuolating leukoencephalopathy). 8,9

The diagnostic characteristic of GCE is an elevated cerebrospinal fluid (CSF) glycine concentration (normal $<12 \mu \mathrm{moll}^{-1}$ ) together

${ }^{1}$ Molecular Diagnostics and Protein Unit, Specialised Diagnostics Centre, Institute for Medical Research, Kuala Lumpur, Malaysia; ${ }^{2}$ UKM Medical Molecular Biology Institute (UMBI), Universiti Kebangsaan Malaysia, Jalan Yaacob Latif, Bandar Tun Razak, Kuala Lumpur, Malaysia; ${ }^{3}$ Genetic Department, Kuala Lumpur Hospital, Jalan Pahang, Kuala Lumpur, Malaysia; ${ }^{4}$ Biochemistry Unit, Specialised Diagnostics Centre, Institute for Medical Research, Kuala Lumpur, Malaysia; ${ }^{5}$ Department of Paediatrics, Hospital Bintulu, Sarawak, Malaysia and ${ }^{6}$ Department of Paediatrics, Hospital Miri, Sarawak, Malaysia

Correspondence: NAA Azize or Professor Dato' Dr WZW Ngah, UKM Medical Molecular Biology Institute (UMBI), Universiti Kebangsaan Malaysia, Jalan Yaacob Latif, Bandar Tun Razak, Cheras, Kuala Lumpur 56000, Malaysia.

E-mail: azimahazize@imr.gov.my or zurina@medic.ukm.my

Received 17 April 2014; revised 11 July 2014; accepted 17 July 2014; published online 18 September 2014 
with an increased CSF-to-plasma glycine ratio $(<0.02$ for normal control ; $>0.08$ for neonatal form; and 0.04-0.2 for atypical form) ${ }^{1,4}$ Confirmatory diagnosis of GCE requires enzymatic and molecular genetics investigation of the glycine cleavage system. GCE can be confirmed by enzymatic assays; however, analysis requires a liver sample that is highly invasive. As such, molecular genetic testing is a much preferred method. The most common defective gene for GCE is the GLDC gene accounting for $80 \%$ of all GCE patients, and up to $15 \%$ have mutated AMT gene. Patients with deficient $\mathrm{H}$-protein enzyme activity were less reported and so far, mutations are not detected for GCSH gene. ${ }^{10}$ Approximately $20 \%$ of GLDC mutant alleles have exonic/multiexonic deletions or duplications. ${ }^{11,12}$ Very rarely, deletions or duplications in AMT have been identified. ${ }^{4}$ Several recurrent mutations in GLDC and AMT have been reported in several populations. ${ }^{4,13}$ About $5 \%$ of patients with enzyme-proven GCE did not have a detectable mutation in any of the above three genes. $^{4}$

The genetic profile for GCE patients in Malaysia has not been reported before. Therefore, this study was aimed to determine mutations in GLDC, AMT and GCSH gene in GCE patients.

\section{MATERIALS AND METHODS}

\section{Study participants}

A total of 14 patients referred to Molecular Diagnostics \& Protein Unit, Institute for Medical Research in the years 2006-2012 were included in the study. These patients exhibited signs and symptoms of GCE as assessed by the pediatricians from Kuala Lumpur Hospital and other hospitals in Malaysia. Fifty blood samples from normal individuals were collected as control for this study. Ethics approval was obtained from the Medical Research \& Ethics Committee, Ministry of Health Malaysia, and written informed consent was obtained from the parents of all patients recruited in the study.

\section{Mutation detection for $A M T, G L D C$ and GCSH gene by direct sequencing}

Peripheral blood sample was collected in EDTA tubes. Genomic DNA was extracted using the QIAamp DNA Mini Kit (Qiagen, Mississauga, ON, Canada), and the DNA quantity and quality were measured using Nanodrop spectrophotometer (Agilent Technologies Inc., Santa Clara, CA, USA). Genomic DNA (100 ng) was subjected to PCR with forward and reverse primers flanking the target sequences. All primers were designed using Primer3 v.0.4.0 software (http://frodo.wi.mit.edu/primer3/). Primers for PCR amplification of all coding exons of the GLDC and GCSH gene contained two universal M13 primer tails at both forward and reverse primers, as shown in Supplementary Tables 1-3. The use of universal primers for the sequencing reactions reduced the time taken in preparation of cycle sequencing.

PCR was performed in a volume of $50 \mu \mathrm{l}$ containing $100 \mathrm{ng}$ genomic DNA, 0.1 U Taq DNA polymerase (Fermentas, Vilnius, Lithuania), 1X of PCR buffer with $\left(\mathrm{NH}_{4}\right)_{2} \mathrm{SO}_{4}-\mathrm{MgCl}_{2}, 1 \mathrm{~mm} \mathrm{MgCl}, 1 \mu \mathrm{mol}$ of each primer and $0.2 \mathrm{~mm}$ of dNTP mix. Dimethyl sulfoxide 100\% $(2 \mu \mathrm{l})$ was added for GLDC and GCSH PCRs. Touchdown PCR program was used to amplify all the exons, except exon 4 of GCSH gene. Exon 4 of GCSH gene was amplified using the normal PCR program with annealing temperature $55^{\circ} \mathrm{C}$. Touchdown PCR was initiated by first denaturing DNA for $3 \mathrm{~min}$ at $95^{\circ} \mathrm{C}$, followed by 10 cycles of $1 \mathrm{~min}$ denaturing at $95^{\circ} \mathrm{C}$, annealing at $60^{\circ} \mathrm{C}$ for $1 \mathrm{~min}$ and extension at $72^{\circ} \mathrm{C}$ for $1 \mathrm{~min}$. The annealing temperature was reduced by $0.5^{\circ} \mathrm{C}$ per cycle for 10 times, followed by 25 cycles of normal PCR conditions starting with denaturation at $95^{\circ} \mathrm{C}$ for $1 \mathrm{~min}, 1 \mathrm{~min}$ of annealing at $55^{\circ} \mathrm{C}$ and $1 \mathrm{~min}$ extension at $72{ }^{\circ} \mathrm{C}$, followed by a final step of complete elongation at $72{ }^{\circ} \mathrm{C}$ for 7 min..$^{20}$ Bidirectional sequencing was performed using BigDye Terminator Cycle Sequencing v3.1 (Applied Biosystems, Foster city, CA, USA) and was separated on a fluorescent Genetic Analyzer ABI 3130 (Applied Biosystems). DNA sequence was then analyzed for mutation using SeqScape software V2.7 (Applied Biosystems).
Deletion and duplication analysis of GLDC gene by MLPA DNA (50 ng) and SALSA MLPA kit P209-B1 GLDC (MRC-Holland, Amsterdam, The Netherlands) assay were used in multiplex ligation-dependent probe amplification (MLPA) for deletion and duplication analysis of GLDC gene following the standard protocol. PCR products were separated using the Genetic Analyzer system ABI 3130. The data obtained were analyzed using GeneMarker V1.85 software (SoftGenetics, State College, PA, USA) and compared with the MLPA panel P209_GLDC_Vs03 and normal control.

\section{Analysis of mutations detected using HomoloGene database, PolyPhen and SIFT software}

All the mutations detected were compared with HomoloGene (NCBI) database to evaluate the percentage of conservation among eukaryote species, whereas PolyPhen and SIFT software were used for protein functions prediction caused by the mutations.

\section{RESULTS}

Patient's demographic data

A total of 14 patients from 13 families were recruited consisting of 8 Malays, 2 Chinese and 4 Penan ethnic. Six of them were females and eight were male patients. Their initial clinical presentation, biochemical characteristics of glycine and severity of psychomotor retardation have been summarized in Table 1 . At onset, all the 14 patients have clinical features consistent with the classical neonatal form of GCE. In one patient, the symptoms spontaneously remit on subsequent follow up.

Thirteen patients have biallelic mutations identified either in AMT (6 patients from 5 families) or GLDC (7 patients from 7 families). In one patient (Patient $\mathrm{K \# 1),} \mathrm{mutation} \mathrm{was} \mathrm{identified} \mathrm{in} \mathrm{only} \mathrm{one} \mathrm{allele}$ despite sequencing of the entire coding regions of the three genes. There was no mutation in GCSH gene being detected in this study. Mutational analyses were performed by direct sequencing followed by MLPA, and the mutation results have been summarized in Table 2.

\section{Mutations in $A M T$ gene}

Four missense mutations (c.664C $>$ T, c.688G $>$ C, c.794G $>$ A, c.826G $>$ C) and one heterozygous deletion causing frameshift mutation (c.982delG) in AMT gene. All these mutations except c.826G $>C$ have not been reported in Human Gene Mutation Database, (http:// www.hgmd.org/). Patients J\#1 and L\#1 of Penan ethnicity have a homozygous c.794G $>$ A mutation detected (Figure 1).

\section{Mutations in GLDC gene}

Nine missense mutations, one nonsense mutation and one heterozygous deletion of exons 3-25 in GLDC gene were reported. Seven of the missense mutations have not yet been reported in Human Gene Mutation Database (http://www.hgmd.org/): c.673T $>$ C, c.883G $>$ T, c. $1114 \mathrm{C}>\mathrm{T}, \mathrm{c} .1525 \mathrm{C}>\mathrm{G}, \mathrm{c} .1607 \mathrm{G}>\mathrm{A}, \mathrm{c} .1789 \mathrm{G}>\mathrm{A}$ and c.2280C $>\mathrm{G}$. The sequencing electropherogram of c.1674C $>$ A mutation in GLDC gene resulted in a premature stop codon and a heterozygous large exonic deletion detected by MLPA identified in Patient D\#1 (Figure 2).

\section{DISCUSSION}

In this study we found biallelic mutations in 13 out of 14 patients with clinical and biochemical features suggestive of GCE; 7 patients have biallelic mutations in GLDC gene and 6 patients in AMT gene. A high proportion of GLDC and AMT mutations in these patients are not previously reported. In 12 out of 13 patients, the biallelic mutations are disease-causing based on the prediction using in silico bioinformatic tools. In one patient (Patient G\#1), the clinical 
Table 1 Patient's demography and clinical presentations

\begin{tabular}{|c|c|c|c|c|c|c|c|c|c|c|c|c|c|c|}
\hline \multirow[b]{2}{*}{$\begin{array}{l}\text { Family } \\
\text { \#Patient }\end{array}$} & \multirow[b]{2}{*}{ Gender } & \multirow[b]{2}{*}{ Ethnicity } & \multirow[b]{2}{*}{$\begin{array}{c}\text { Parental } \\
\text { consanguinity }\end{array}$} & \multicolumn{7}{|c|}{ Initial clinical presentation } & \multirow[b]{2}{*}{$\begin{array}{l}\text { CSF } \\
\text { glycine }\end{array}$} & \multirow[b]{2}{*}{$\begin{array}{l}\text { CSF:plasma } \\
\text { glycine ratio }\end{array}$} & \multirow[b]{2}{*}{$\begin{array}{c}\text { CNS } \\
\text { imaging }\end{array}$} & \multirow{2}{*}{$\begin{array}{l}\text { Outcome-severity } \\
\text { of psychomotor } \\
\text { retardation }\end{array}$} \\
\hline & & & & Age & Hypotonia & $\begin{array}{c}\text { Poor } \\
\text { sucking }\end{array}$ & Hiccup & Apnea & Seizure & $E E G$ & & & & \\
\hline A\#1 & Female & Chinese & - & 1st day & + & + & - & + & + & BS & 439 & 0.38 & $\mathrm{HCC}$ & Severe \\
\hline B\#1 & Female & Malay & - & 2nd day & + & + & - & + & + & BS & 130 & 0.11 & $\mathrm{HCC}$ & Moderate \\
\hline B\#2 & Male & Malay & - & 4th day & + & + & - & - & + & NA & 122 & 0.12 & NA & Moderate \\
\hline C\#1 & Male & Penan & - & 3rd day & + & + & - & + & - & NA & 651 & 0.24 & NA & Died (6th day) \\
\hline D\#1 & Male & Malay & - & 1st day & + & + & + & + & - & NA & 292 & 0.13 & $\mathrm{HCC}$ & Died (1st month) \\
\hline E\#1 & Male & Chinese & - & 1st day & + & + & + & + & + & BS & 200.4 & 0.17 & $\mathrm{HCC}$ & Severe \\
\hline F\#1 & Female & Malay & - & 2nd day & + & + & + & + & + & $\mathrm{BS}$ & 306 & 0.17 & $\mathrm{HCC}$ & Severe (died 5 years) \\
\hline G\#1 & Female & Malay & + & 1st day & + & + & - & + & + & $\mathrm{SP}$ & 207 & 0.37 & WM & None \\
\hline $\mathrm{H} \# 1$ & Female & Malay & - & 2nd day & + & + & + & + & + & BS & 207 & 0.24 & $\mathrm{HCC}$ & Severe \\
\hline I\#1 & Female & Penan & - & 1st day & + & + & + & + & + & NA & 200 & 0.36 & NA & Severe \\
\hline J\#1 & Male & Penan & - & 1st day & + & + & - & + & + & NA & 153 & 0.17 & NA & Severe \\
\hline K\#1 & Male & Malay & - & 4th day & + & + & - & + & + & NA & 103 & 0.12 & $\mathrm{Cl}$ & Severe \\
\hline L\#1 & Male & Penan & - & 5th day & + & + & + & + & + & NA & 306 & 0.10 & NA & Died \\
\hline $\mathrm{M \# 1}$ & Male & Malay & - & 14th day & + & + & - & + & + & NA & 202 & 0.11 & NA & Died \\
\hline
\end{tabular}

Abbreviations: BS, burst suppression; $\mathrm{Cl}$, cerebral infarct; CNS, central nervous system; CSF, cerebrospinal fluid; EEG, electroencephalogram; HCC, hypogenesis of corpus callosum; NA, not available; SP, abnormal spikes; WM, white matter signal abnormalities.

${ }^{a}$ CSF glycine measured in $\mu \mathrm{mol} \mathrm{I}^{-1}$ and normal control is $<12$.

Table 2 Mutations of $A M T$ and GLDC genes of GCE patients

\begin{tabular}{|c|c|c|c|c|c|c|c|c|c|}
\hline $\begin{array}{l}\text { Family/ } \\
\text { \#Patient }\end{array}$ & Gene/exon & $\begin{array}{c}\text { Nucleotide } \\
\text { changes }\end{array}$ & $\begin{array}{l}\text { Amino acid } \\
\text { changes }\end{array}$ & $\begin{array}{l}\text { Type of } \\
\text { mutations }\end{array}$ & $\begin{array}{l}\text { Mutation } \\
\text { state }\end{array}$ & $\begin{array}{c}\text { Gene } \\
\text { conserved in } \\
\text { eukaryota (\%) }\end{array}$ & $\begin{array}{l}\text { Protein function } \\
\text { prediction } \\
\text { by PolyPhen }\end{array}$ & $\begin{array}{c}\text { Protein } \\
\text { function } \\
\text { prediction } \\
\text { by SIFT }\end{array}$ & Reference \\
\hline \multirow[t]{2}{*}{ A\#1 } & AMT/7 & c. $826 \mathrm{G}>\mathrm{C}$ & p.Asp276His & Missense & Heterozygous & 100 & Probably damaging & Affect & 15 \\
\hline & AMT/8 & c.982delG & p.Ala328fs & Frameshift & Heterozygous & 44 & NA & NA & Novel \\
\hline \multirow[t]{2}{*}{$\mathrm{B} \# 1$} & AMT/6 & c. $664 \mathrm{C}>\mathrm{T}$ & p.Arg222Cys & Missense & Heterozygous & 100 & Probably damaging & Affect & Novel \\
\hline & AMT/6 & c. $688 \mathrm{G}>\mathrm{C}$ & p.Gly230Arg & Missense & Heterozygous & 100 & Probably damaging & Affect & Novel \\
\hline \multirow[t]{2}{*}{ B\#2 } & AMT/6 & c. $664 \mathrm{C}>\mathrm{T}$ & p.Arg222Cys & Missense & Heterozygous & 100 & Probably damaging & Affect & Novel \\
\hline & AMT/6 & c. $688 \mathrm{G}>\mathrm{C}$ & p.Gly230Arg & Missense & Heterozygous & 100 & Probably damaging & Affect & Novel \\
\hline \multirow[t]{2}{*}{ C\#1 } & AMT/7 & c. $794 \mathrm{G}>\mathrm{A}$ & p.Arg265His & Missense & Homozygous & 100 & Probably damaging & Affect & Novel \\
\hline & $G L D C / 17$ & c. $1952 A>G$ & p.His651Arg & Missense & Heterozygous & 100 & Probably damaging & Affect & 12 \\
\hline \multirow[t]{2}{*}{ D\#1 } & $G L D C / 14$ & c. $1674 C>A$ & p.Cys558Stop Codon & Nonsense & Heterozygous & 100 & NA & NA & Novel \\
\hline & $\begin{array}{c}G L D C / 3- \\
25\end{array}$ & Del one allele $G L D C$ & Del one allele $G L D C$ & Large deletion & Heterozygous & NA & NA & NA & Novel \\
\hline \multirow[t]{2}{*}{ E\#1 } & $G L D C / 7$ & c. $883 \mathrm{G}>\mathrm{T}$ & p.Asp295Tyr & Missense & Heterozygous & 94 & Probably damaging & Affect & Novel \\
\hline & $G L D C / 13$ & c. $1607 \mathrm{G}>\mathrm{A}$ & p.Arg536Glu & Missense & Heterozygous & 100 & Probably damaging & Affect & Novel \\
\hline \multirow[t]{2}{*}{$\mathrm{F} \# 1$} & $G L D C / 4$ & c. $605 \mathrm{C}>\mathrm{T}$ & p.Ala202Val & Missense & Heterozygous & 100 & Probably damaging & Affect & 16 \\
\hline & $G L D C / 19$ & c. $2280 C>G$ & p.His760GIn & Missense & Heterozygous & 95 & Probably damaging & Affect & Novel \\
\hline \multirow[t]{2}{*}{ G\#1 } & $G L D C / 12$ & c. $1525 C>G$ & p.Pro509Ala & Missense & Heterozygous & 19 & Possibly damaging & Tolerate & Novel $^{a}$ \\
\hline & $G L D C / 15$ & c. $1789 \mathrm{G}>\mathrm{A}$ & p.Glu597Lys & Missense & Heterozygous & 33 & Benign & Tolerate & Novel ${ }^{a}$ \\
\hline $\mathrm{H} \# 1$ & $G L D C / 8$ & c. $1114 \mathrm{~A}>\mathrm{T}$ & p.lle372Phe & Missense & Homozygous & 100 & Probably damaging & Affect & Novel \\
\hline I\#1 & $G L D C / 17$ & c. $1952 A>G$ & p.His651Arg & Missense & Homozygous & 100 & Probably damaging & Affect & 12 \\
\hline J\#1 & AMT/7 & c. $794 \mathrm{G}>\mathrm{A}$ & p.Arg265His & Missense & Homozygous & 100 & Probably damaging & Affect & Novel \\
\hline K\#1 & $G L D C / 8$ & c. $1114 \mathrm{~A}>\mathrm{T}$ & p.lle372Phe & Missense & Heterozygous & 100 & Probably damaging & Affect & Novel \\
\hline L\#1 & AMT/7 & c. $794 \mathrm{G}>\mathrm{A}$ & p.Arg265His & Missense & Homozygous & 100 & Probably damaging & Affect & Novel \\
\hline M\#1 & $G L D C / 5$ & c. $673 \mathrm{~T}>\mathrm{C}$ & p.Cys225Arg & Missense & Homozygous & 67 & Probably damaging & Affect & Novel \\
\hline
\end{tabular}

Abbreviations: AMT, aminomethyltransferase; GCE, glycine encephalopathy; GLDC, glycine decarboxylase; NA, not available. ${ }^{a} \mathrm{C}$ linical significance uncertain.

significance of the biallelic mutations is uncertain. The high mutation rate in the GLDC gene resulting in GCE is similar to previous reports. ${ }^{4,10}$ Recently, defects of lipoate biosynthesis and related iron sulfur cluster biogenesis genes, including LIAS, BOLA3 and GLRX5, have been identified to be causative for some patients with GCE without disease-causing mutations identified in gene encoding a 
A

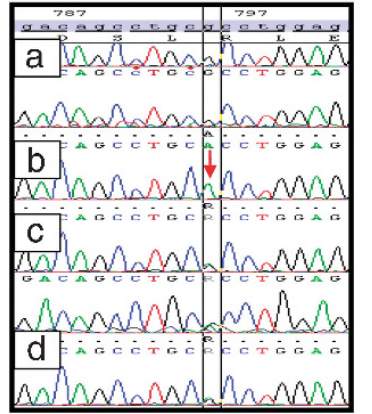

B

Homo sapions Pan trogiodytes Canis lupus fam
Bos taurus Mus musculus Rattus nonvegicus Danio rerio Drasophila melanogaster Anopheles gambize Caenorhabditis elegans Schizosaccharomyces pom Saccharomyces cerevisia Kinyveromyces lactis Magnaporthe grisea Neurospora crassa Arabidopsis thaliana Onyze sative Plasmodium falciparum c. $794 \mathrm{G}>\mathrm{A}$

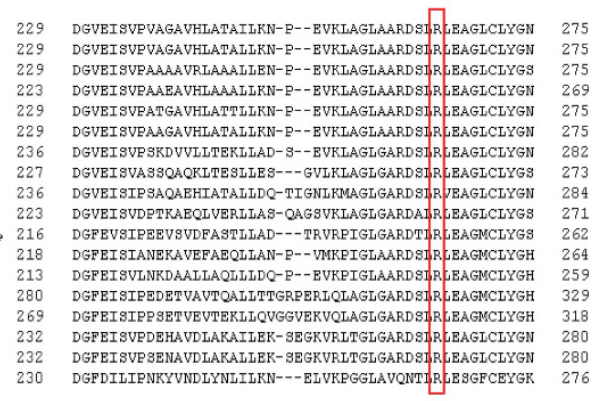

Figure 1 Mutation analysis of Patients $\mathrm{J \# 1}$ with the sequencing electropherogram showed a homozygous C.794G $>$ A mutation (A), and the homologene sequence showed the position of the mutation and the conserved amino acid (B); a: normal control, b: Patient J\#1, c: mother and d: father.

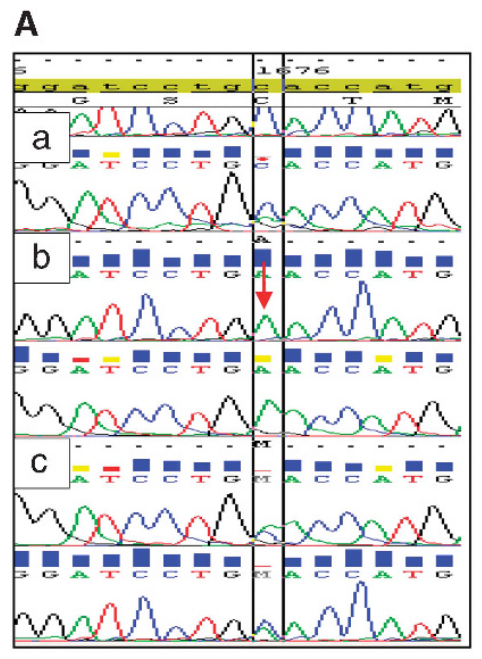

B

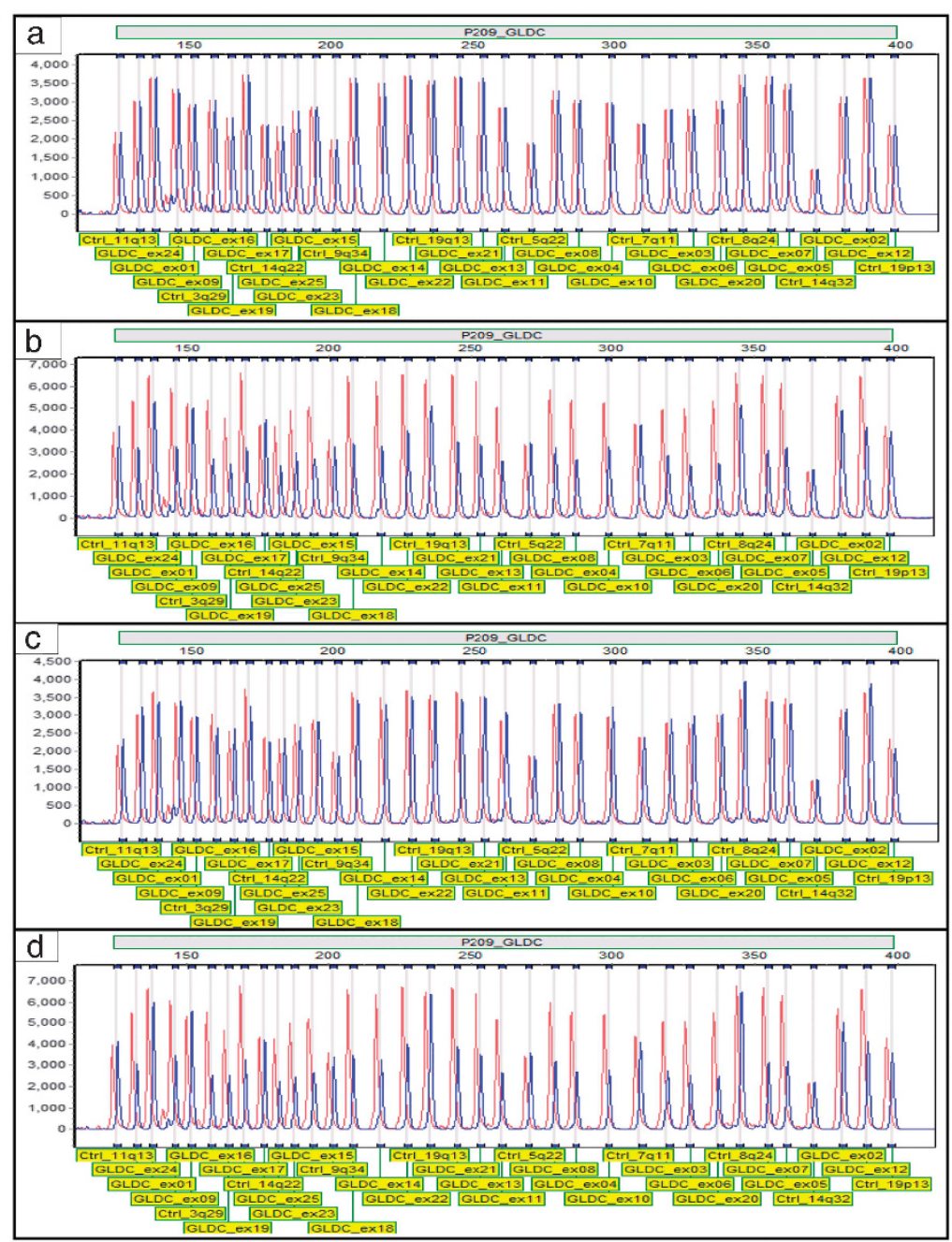

Figure 2 Mutation analysis of Patient D\#1 with the sequencing electropherogram showed mutation at $\mathrm{C} .1674 \mathrm{C}>\mathrm{A}$ in GLDC gene resulting premature stop codon (A); a: normal control, b: Patient D\#1, c: mother, and the MLPA results showed the heterozygous deletion of exons 3-25 of GLDC gene (B); a: normal control, b: Patient D\#1, c: mother and d: father.

constituent of the glycine cleavage enzyme. ${ }^{14}$ We did not study these genes in the single patient without biallelic mutations detected.

Most of the mutations detected are single family mutation except for patients from Penan ethnicity. The Penans are nomadic aboriginal people living in Sarawak, one of the states of East Malaysia located in
Borneo Island. There are a total of 16 GCE patients registered in Malaysia, 4 of them are Penan patients. Although the prevalence of GCE in Malaysia is estimated at 1:187 500 newborns, it is possible that the prevalence among the Penans may be higher. Two mutations c.1952A $>$ G (p.His651Arg) in GLDC gene and c.794G >A 
(p.Arg265His) in AMT gene are observed exclusively in the Penan patients. Further study to determine the carrier frequency of the two mutations among the Penans is currently constrained by difficulties to get control subjects among this nomadic population, who mostly stay at geographically remote areas.

All the patients in this study have clinical features of classical neonatal form of GCE. Probably the late-onset and atypical forms of GCE are still unrecognized in our population and may require further study. Almost all the patients in this study have devastating neurological outcome except Patient G\#1. This patient was born at full-term gestation to consanguineous parents with birth weight of $2.9 \mathrm{~kg}$. She developed feeding problem and cyanosis after a few hours, fitted on the second day and became apneic needing ventilator support. She regained spontaneous respiration 1 week later. She was treated with dextromethorphan and sodium benzoate. Her developmental milestones were normal. Dextromethorphan and sodium benzoate were taken off subsequently. A repeat CSF glycine analysis at 5 years old was normal $(11.4 \mu \mathrm{M})$. To date, she remains seizure free and neurologically normal. She attended normal school and academic performance has been good. It is most likely that she is in the category of transient GCE. Genetic analysis revealed two mutations of unknown significance in GLDC: compound heterozygous c.1525C > G (p.Pro509Ala) and c.1789G >A (p.Glu597Lys), whereas her parents were found to be heterozygous carriers. For mutation c. $1525 \mathrm{C}>\mathrm{G}$, a protein function prediction by PolyPhen suggested a possible damaging effect but prediction by SIFT suggested that it is tolerable. Whereas for mutation c.1789G $>$ A, analyses by both software suggested a tolerable effect. Both mutations were not found in 50 control subjects of the same ethnicity. Search on Mutation Taster database (http://www.mutationtaster.org/) showed both mutations are not listed as single-nucleotide polymorphism. ${ }^{15}$ Therefore, we are unable to conclude definitely if her clinical symptom was indeed caused by GLDC mutations. Transient GCE remains a controversial diagnosis. It is clinically and biochemically indistinguishable from GCE at onset. Heterozygous GLDC and GCSH gene mutations have been reported in three patients with transient GCE , suggesting that transient GCE may develop in some heterozygous carriers. ${ }^{16}$ Although CSF hyperglycinemia and elevated CSF:plasma glycine ratio in an infant with acute encephalopathy are considered highly characteristic of GCE, similar findings can be encountered in a variety of clinical conditions including hypoxic ischemic encephalopathy. ${ }^{17}$ Our experience with Patient G\#1 illustrated the potential pitfall and difficulties in confirming the diagnosis of transient GCE.

In conclusion, the genetic mutations of Malaysian children with GCE had been studied, and we found that mutations in both the GLDC and AMT genes are the main causes of GCE in the population.

\section{CONFLICT OF INTEREST}

The authors declare no conflict of interest.

\section{ACKNOWLEDGEMENTS}

We thank the Director General of Health Malaysia for permission to publish this paper. We express our gratitude to Lizaros Ahamad Sohor, Nurul Yusnita Jaffar and all staff of Molecular Diagnostics and Protein Unit, Institute for Medical Research for their technical assistance. We also thank patients' parents for their agreement to participate in this study. Our special thanks to Dr Shahnaz Murad, Director of IMR, Dr Rohani Md Yasin and Yusnita Yakob for critical reading of the manuscript and valuable comments. This research was supported by the National Institute of Health Malaysia.

1 Jaeken, J., de Koning, T. \& van Hove, J. in: Physician's Guide to the Laboratory Diagnosis of Metabolic Diseases, 2nd edn (eds Blau, N., Duran, M., Blaskovics, M. E. \& Gibson, K. M.) 123-140 (Springer, Berlin, 2002)

2 Sakata, Y., Owada, Y., Sato, K., Kojima, K., Hisanaga, K., Shinka, T. et al. Structure and expression of the glycine cleavage system in rat central nervous system. Brain Res. Mol. Brain Res. 94, 119-130 (2001).

3 Kikuchi, G., Motokawa, Y., Yoshida, T. \& Hiraga, K. Glycine cleavage system: reaction mechanism, physiological significance, and hyperglycinemia. Proc. Jpn Acad. Ser. B Phys. Biol. Sci. 84, 246-263 (2008).

4 Hamosh, A., Scharer, G. \& Van Hove, J. in Glycine encephalopathy (14 November 2002 (Updated 11 July 2013)). (eds Pagon, R. A., Bird, T. D., Dolan, C. R., Coughlin, C., Applegarth, D. A. \& Toone, J.) (University of Washington, Seattle, Seattle, WA, 1993) Available from: http://www.ncbi.nlm.nih.gov/books/NBK1357/

5 Hoover-Fong, J. E., Shah, S., Van Hove, J. L. K., Applegarth, D., Toone, J. \& Hamosh, A. Natural history of nonketotic hyperglycinemia in 65 patients. Neurology 63, 1847-1853 (2004).

6 Hennermann, J. B., Berger, J. M., Grieben, U., Scharer, G. \& Van Hove, J. L. Prediction of long-term outcome in glycine encephalopathy: a clinical survey. J. Inherit. Metab. Dis. 35, 253-261 (2012).

7 Hennermann, J. B. Clinical variability in glycine encephalopathy. Future Neurol. 1, 621-630 (2006).

8 Menéndez, S. J. J., Del Cerro, M. M. J., Dorao, M. R. P., Labrandero de, L. C. Fernández, G. M. L. \& Rodríguez, G. J. I. Nonketotic hyperglycinemia presenting as pulmonary hypertensive vascular disease and fatal pulmonary edema in response to pulmonary vasodilator therapy. J. Pediatr. 161, 557-559 (2012).

9 Chiong, M. A., Procopis, P., Carpenter, K. \& Wilcken, B. Late-onset nonketotic hyperglycinemia with leukodystrophy and an unusual clinical course. Pediatr. Neurol. 37, 283-286 (2007)

10 Kure, S., Kato, K., Dinopoulos, A., Gail, C., DeGrauw, T. J., Christodoulou, J. et al. Comprehensive mutation analysis of GLDC, AMT and GCSH in nonketotic hyperglycinemia. Hum. Mutat. 27, 343-352 (2006).

11 Conter, C., Rolland, M. O., Cheillan, D., Bonnet, V., Maire, I. \& Froissart, R. Genetic heterogeneity of the GLDC gene in 28 unrelated patients with glycine encephalopathy. J. Inherit. Metab. Dis. 29, 135-142 (2006).

12 Kanno, J., Hutchin, T., Kamada, F., Narisawa, A., Aoki, Y., Matsubara, Y. et al. Genomic deletion within GLDC is a major cause of non-ketotic hyperglycinemia. J. Med. Genet. 44, e69 (2007).

13 Boneh, A., Korman, S. H., Sato, K., Kanno, J., Matsubara, Y., Lere, I. et al. A single nucleotide substitution that abolished the initiator methionine codon of the GLDC gene is prevalent among patients with glycine encephalopathy in Jerusalem. J. Hum. Genet. 50, 230-234 (2005).

14 Baker, P. R. II, Friederich, M. W., Swanson, M. A., Shaikh, T., Bhattacharya, K., Scharer, G. H. et al. Variant non ketotic hyperglycinemia is caused by mutations in LIAS, BOLA3 and the novel gene GLRX5. Brain 137, 366-379 (2014).

15 Schwarz, J. M., Rödelsperger, C., Schuelke, M. \& Seelow, D. MutationTaster evaluates disease-causing potential of sequence alterations. Nat. Methods 7, 575-576 (2010).

16 Kure, S., Kojima, K., Ichinohe, A., Maeda, T., Kalmanchey, R., Fekete, G. et al. Heterozygous GLDC and GCSH gene mutations in transient neonatal hyperglycinemia. Ann. Neurol. 52, 643-646 (2002).

17 Aburahma, S., Khassawneh, M., Griebel, M., Sharp, G. \& Gibson, J. Pitfalls in measuring cerebrospinal fluid glycine levels in infants with encephalopathy. J. Child. Neurol. 26, 703-706 (2011).

Supplementary Information accompanies the paper on Journal of Human Genetics website (http://www.nature.com/jhg) 